\title{
Author Correction: Variation of a major facilitator superfamily gene contributes to differential cadmium accumulation between rice subspecies
}

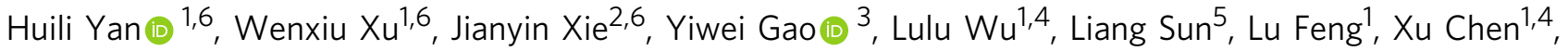 \\ Tian Zhang ${ }^{1,4}$, Changhua Dai ${ }^{1,4}$, Ting Li (10 1,4, Xiuni Lin ${ }^{3}$, Zhanying Zhang ${ }^{2}$, Xueqiang Wang ${ }^{2}$, Fengmei Li²,

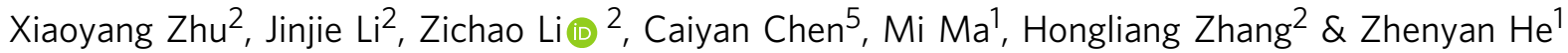

Correction to: Nature Communications https://doi.org/10.1038/s41467-019-10544-y, published online 12 June 2019.

The original version of this Article did not acknowledge Jianyin Xie as an equally contributing author with a superscript 6 . Also, there was an error in the second sentence of the Abstract, which incorrectly read 'While several transport systems have been reported, the complicity of rice $\mathrm{Cd}$ transport and accumulation indicates the necessity of identifying additional genes, especially those that are responsible for $\mathrm{Cd}$ accumulation divergence between indica and japonica rice subspecies.' The correct version states 'complexity' in place of 'complicity'. This has now been corrected in both the PDF and HTML versions of the Article.

Published online: 19 July 2019

Open Access This article is licensed under a Creative Commons Attribution 4.0 International License, which permits use, sharing, adaptation, distribution and reproduction in any medium or format, as long as you give appropriate credit to the original author(s) and the source, provide a link to the Creative Commons license, and indicate if changes were made. The images or other third party material in this article are included in the article's Creative Commons license, unless indicated otherwise in a credit line to the material. If material is not included in the article's Creative Commons license and your intended use is not permitted by statutory regulation or exceeds the permitted use, you will need to obtain permission directly from the copyright holder. To view a copy of this license, visit http://creativecommons.org/licenses/by/4.0/.

(c) The Author(s) 2019

\footnotetext{
${ }^{1}$ Key Laboratory of Plant Resources, Institute of Botany, Chinese Academy of Sciences, Beijing 100093, China. ${ }^{2}$ Key Lab of Crop Heterosis and Utilization of Ministry of Education, Beijing Key Lab of Crop Genetic Improvement, China Agricultural University, Beijing 100193, China. ${ }^{3}$ College of Biological Sciences and Biotechnology, Beijing Forestry University, Beijing 100083, China. ${ }^{4}$ University of Chinese Academy of Sciences, Beijing 100049 , China. ${ }^{5}$ Key Laboratory of Agro-Ecological Processes in Subtropical Region, Institute of Subtropical Agriculture, Chinese Academy of Sciences, Changsha 410125, China. ${ }^{6}$ These authors contributed equally: Huili Yan, Wenxiu Xu, Jianyin Xie. Correspondence and requests for materials should be addressed to H.Z. (email: zhangl@cau.edu.cn) or to Z.H. (email: hezhenyan@ibcas.ac.cn)
} 